Author's Conrtibution

A - Study Design

B - Data Collection

C - Statistical Analysis

D - Data Interpretation

E - Manuscript Preparation

$\mathrm{F}$ - Literature Search

G - Funds Collection

\section{Body Mass Index in Female First-Year Students of Full-Time Studies at the Academy of Physical Education and Sport in Gdansk: Reality, Self-Evaluation, Dreams}

\section{Ewa Wójtowicz}

Jedrzej Sniadecki Academy of Physical Education and Sport in Gdansk, Poland

Key words: real BMI, subjective BMI, BMI in dreams, female students

\section{Materials and methods:}

Results:

Conclusions:

\section{Abstract}

An image on one's body is an important component of one's mental welfare. Scientific reports suggest that girls and women have a tendency to evaluate themselves through the prism of physical appearance and gender expectations influenced by cultural and unrealistic standards of beauty (slim, very lean, boy-like silhouette). The purpose of this study was to find out the opinions of young, healthy and physically active women about their bodies (BMI self-evaluation) and the ones connected with their dreams (the most satisfactory BMI) and reality (anthropometric measurements).

The statistical analysis of the data was based on anthropometric measurements and a survey conducted on female students $(N=1,394)$ from the first year of full-time studies at the Academy of Physical Education and Sport in Gdansk in the years 2000-2007.

Overweight or obesity occurred in $5.9 \%$ of students. By contrast, during selfevaluation $30.62 \%$ of the women declared overweight or obesity. In self-evaluation among the tested group of students $29.17 \%$ of women with normal body weight claimed to have a higher BMI, and only $1.85 \%$ to have a lower one. It this group of young women, $59.97 \%$ are satisfied with their BMI (selfevaluation and dreams overlap).

The examined women do not have skills to properly assess their BMI, which, in turn, can lead to eating disorders. BMI evaluation should not be based solely on information obtained in young women's BMI self-evaluation. Education is necessary for continuous monitoring and correcting the body's dimensions.

$\begin{array}{lrrr}\text { Word count: } & 5020 & & \\ \text { Tables: } & 8 & \text { Received: } & \text { September } 2010 \\ \text { Figures: } & 0 & \text { Accepted: } & \text { December } 2011 \\ \text { References: } & 34 & \text { Published: } & \text { March } 2011\end{array}$

Address for correspondence

Dr Ewa Wójtowicz, Academy of Physical Education and Sport, Department of Anatomy and Anthropology,

80-336 Gdańsk, Poland, ul. K. Górskiego 1, Phone: +4858 554-71-09, e-mail: ewawoj14@wp.pl 


\section{Introduction}

Nutrition is one of the most important environmental factors determining the biological value and health of human populations. Evaluation of the nutritional status (shortage or excess of nutrients) is carried out through biochemical studies and anthropometric measurements [1]. Evaluation of the ratio of body weight to height, circumference of body parts, and skin folds thickness are used as measures of the nutritional status [1].

Requirements regarding human nutrition depend on a number of bio-geographical and sociocivilization factors (such as age, gender, type of work performed, the body size, season of the year, health status). Food provides energy required for proper functioning of the body (including the action of muscles, mental work, and retaining constant body temperature, ontogenesis and reproduction) [1].

Eating disorders are becoming nowadays not only a medical but also a social problem. This is demonstrated by both the literature review, as well as information from mass-media [2]. Problems associated with eating disorders do not constitute only the social and cultural aspect. They are not only limited to issues of food and the dimensions of the body. Eating disorders are inextricably linked with internal conflicts, emotional problems and definition of one's own identity and negative self-image and the problems associated with the course of psychosexual development [2]. It is well known that taking care of one's body will reduce the risk of many diseases. There is also a widespread assumption that, if we are slim, we will find a better partner in life, we will find a better job, we will be happier, we will achieve success in life, we will be more sexually attractive and more confident in ourselves $[2,3,4]$. The ascertainment "slim is better" is omnipresent. The mass-media have a particular influence on the development of models and ideals (the body, appearance, figure). Images taken from the press, radio and television very often produce patterns among adolescents connected with a sense of a gap between the "ideal body" and "one's own body". This triggers constant anxiety about appearance or body weight and inclines one to take measures to reduce this anxiety. Most frequently, this is the control of the body weight primarily through diet $[5,6]$. An image of one's body is an important component of one's mental welfare. Scientific reports suggest that girls and women tend to evaluate themselves through the prism of physical appearance and gender expectations influenced by cultural and unrealistic standards of beauty (slim, very lean, boy's silhouette) [7]. The shift towards the ideal of lean body coincides with a higher prevalence of overweight and obesity [2]. Overweight and obesity are the results of over-supply of energy consumed in the diet in relation to the needs of the body, which results in excessive storage of body fat. In more than $90 \%$ of the obese, obesity is the cause of abnormal energy balance, which results from the competitive power of the energy spent on food [8]. People with excessive body weight suffer from diabetes, hypertension, hyperlipidemia, atherosclerosis, ischemic heart disease, certain cancers, liver disease, joint disease, hormonal disorders or chronic obstructive pulmonary disease more often than the general population $[9,10,11,12]$. In addition to health risks, obesity and dissatisfaction with the actual construction of the body (primarily body weight) are often associated with major psychological and social problems, such as low self-esteem, social isolation, depressive states. For many people, their external appearance significantly shapes their self-esteem and identity. This creates the mental picture of the body, including the image itself. This idea and its conformity with reality are important. It influences thinking, experience and activities of a human being [5]. The research results suggest that the image of one's own body, sexual attractiveness, physical condition and acceptance of body weight for women is a major determinant of the overall sense of happiness in life [13]. In addition, one's body image or the image generated under the influence of internal stimuli need not be consistent with the actual facts [5]. Nutritional disorders are an important medical and social problem. Knowledge on health behaviours, lifestyles, perceptions and satisfaction with one's own build are a foundation for creating pro-health programs and actions. 


\section{Material and Methods}

The statistical analysis of the data is based on anthropometric measurements and a survey conducted on female students $(\mathrm{N}=1394)$ from the first year of full-time studies at the Academy of Physical Education and Sport in Gdansk in the years 2000-2007. The examined students are healthy, fit and physically active women at the turn of adolescence and adult age. Anthropometric measurements were performed each year in the same period on the same person. Before proceeding to the anthropometric measurements the tested students filled in a questionnaire, which asked them, among others, about the most satisfying for them BMI category (underweight, normal weight, overweight, obesity, extreme obesity).

Female students also engaged in BMI self-evaluation by selecting one of the categories of the index (underweight, normal weight, overweight, obesity, extreme obesity). Measurements of body height, weight and the skin folds thickness were performed in accordance with the rules [1]. Anthropometric measurements performed by medical weight (body weight), anthropometer (body height) and skin fold calliper (the skin folds thickness on the right side of the body: under scapula, on the back of an arm, on abdomen). The density of the body was calculated by Piechaczek's formula [14] using the three skin folds thicknesses: under scapula, on the back of an arm, on abdomen. Total body fat percentage of body weight $(\mathrm{F} \%)$ was calculated by Keys and Brożek's formula [14]. Total body fat in kilograms (Fkg) was calculated using the formula: $\mathrm{Fkg}=($ body mass $[\mathrm{kg}] \times \mathrm{F} \%): 100 \%$. Active cell of body mass in percentage (TA\%) was calculated from the formula: TA $\%=100 \%-F \%$. The value of the proper body mass was defined using Body Mass Index (BMI) according to the following formula:

$\mathrm{BMI}=$ Body mass $[\mathrm{kg}]:(\mathrm{B}-\mathrm{v})^{2}[\mathrm{~m}]$. The following ranges of BMI values were considered [15]:

$\mathrm{BMI}<18,5 \mathrm{~kg} / \mathrm{m}^{2}$ - underweight,

$18.5 \mathrm{~kg} / \mathrm{m}^{2} \leq \mathrm{BMI}<25.0 \mathrm{~kg} / \mathrm{m}^{2}-$ normal weight,

$25.0 \mathrm{~kg} / \mathrm{m}^{2} \leq \mathrm{BMI}<30.0 \mathrm{~kg} / \mathrm{m}^{2}-$ overweight,

$30.0 \mathrm{~kg} / \mathrm{m}^{2} \leq \mathrm{BMI}<40.0 \mathrm{~kg} / \mathrm{m}^{2}$ - obesity,

$40.0 \mathrm{~kg} / \mathrm{m}^{2} \geq \mathrm{BMI}$ - extreme obesity.

Statistical analysis of the results was conducted using Statistica 6.0 software. For continuous variables, the normality of distributions was verified using Shapiro-Wilk's test. In cases of abnormal distributions, medians were used and the differences between them were tested using Kruskal-Wallis test or Mann-Whitney test. A correlation link between quantitative variables was estimated calculating the Spearman rank-order correlation coefficient. The differences in the numbers of observations during different stages of the analysis result from the lack of respondents' consent to use the information contained in the questionnaire for research purposes.

The purpose of this study was to find out the opinions of young, healthy and physically active women about their bodies (BMI self-evaluation) and the ones preoccupied with their dream opinion (the most satisfactory BMI) and reality (anthropometric measurements).

\section{Results}

The overall characteristics of the quantitative variables analysed in the group of women, the first-year full-time students at Jędrzej Śniadecki Academy of Physical Education and Sport in Gdansk, are presented in Table 1.

There was no significant statistical relationship between the respondents' years of birth and the value of their BMI ratio ( $p>0.05)$ or between their years of birth and the percentage of the women in various BMI categories calculated on the basis of anthropometric measurements $(p>0.05)$. Also, the BMI index ( $p>0.05)$ did not show a statistically significant variation according to the year of birth. Therefore, the subsequent stages of analysis do not take into account the surveyed women's years of birth. 
Tab .1. General characteristics of the quantitative variables - first-year female student of full-time studies at the Academy of Physical Education and Sport in Gdansk (2000-2007)

\begin{tabular}{|c|c|c|c|c|c|c|}
\hline Variable & $\mathbf{N}$ & M & SD & Q25 & Me & Q75 \\
\hline Calendar age [years] & 1409 & 20.69 & 0.67 & 20.0 & 20.0 & 20.0 \\
\hline Body weight [kg] & 1394 & 60.89 & 7.58 & 55.60 & 60.10 & 65.40 \\
\hline Body height [cm] & 1394 & 167.86 & 6.22 & 163.70 & 167.60 & 171.70 \\
\hline BMI $\left[\mathrm{kg} / \mathrm{m}^{2}\right]$ & 1394 & 21.58 & 2.13 & 20.12 & 21.33 & 22.87 \\
\hline $\mathrm{F}$ on the back of an arm [mm] & 1394 & 4.01 & 1.69 & 3.0 & 3.4 & 4.6 \\
\hline F under scapula [mm] & 1394 & 11.65 & 4.40 & 8.8 & 10.60 & 13.40 \\
\hline F on abdomen [mm] & 1393 & 10.20 & 4.59 & 7.20 & 9.0 & 12.0 \\
\hline $\mathrm{D}$ & 1394 & 1.06 & 0.008 & 1.05 & 1.056 & 1.06 \\
\hline $\mathrm{F} \%$ & 1394 & 16.65 & 3.14 & 14.52 & 16.47 & 18.64 \\
\hline Fkg & 1394 & 10.23 & 2.75 & 8.35 & 9.95 & 11.75 \\
\hline TA\% & 1394 & 83.35 & 3.14 & 81.36 & 83.53 & 85.48 \\
\hline TAkg & 1394 & 50.65 & 5.81 & 46.76 & 50.08 & 53.93 \\
\hline
\end{tabular}

F - the skin folds thickness on the right side of the body

The presence of a statistically significant correlation between density of the body and skin folds thickness (under scapula, on the back of an arm, on abdomen) allowed assessing the fatty tissue of the body by means of the method proposed by Piechaczek [17]. Correlation coefficients for skin folds thickness had the following values: under scapula $(R=-0.64 ; p=0.00000)$, on the back of an arm $(R=-0.78 ; p=0.00000)$, on abdomen $(R=-0.81 ; p=0.00000)$.

Tab. 2. General characteristics of the quantitative variables - first-year female students of full-time studies at the Academy of Physical Education and Sport in Gdansk (2000-2007) - in categories of real BMI

\begin{tabular}{|c|c|c|c|c|c|c|c|c|c|c|c|c|}
\hline $\mathrm{N}$ & $M$ & SD & Q25 & $\mathrm{Me}$ & Q75 & \multirow[b]{2}{*}{$\mathrm{BMI}^{*}$} & $\mathrm{~N}$ & $M$ & SD & Q25 & $\mathrm{Me}$ & Q75 \\
\hline \multicolumn{6}{|c|}{$R=0.07 \quad p=0.01 / x^{2}=140.22 \quad p=0.000$} & & \multicolumn{6}{|c|}{$\begin{array}{c}\text { Body height }[\mathrm{cm}]^{*} \\
R=-0.03 \quad p=0.25 / x^{2}=1.02 \quad p=0.6\end{array}$} \\
\hline 66 & 50.27 & 4.28 & 47.30 & 49.60 & 54.00 & UW & 66 & 167.75 & 6.69 & 163.30 & 166.45 & 171.30 \\
\hline 1246 & 60.56 & 6.41 & 55.80 & 60.00 & 64.80 & NW & 1246 & 167.89 & 6.17 & 164.00 & 167.70 & 172.00 \\
\hline 78 & 73.41 & 5.99 & 69.00 & 72.50 & 76.40 & OW & 78 & 167.31 & 6.42 & 163.00 & 167.75 & 170.70 \\
\hline 4 & 94.13 & 16.31 & 83.75 & 90.50 & 104.50 & $\mathrm{OB}$ & 4 & 169.98 & 9.84 & 163.75 & 171.65 & 176.20 \\
\hline 0 & & & & & & EOB & 0 & & & & & \\
\hline \multicolumn{6}{|c|}{$\begin{array}{l}\text { Body Mass Index }\left[\mathrm{kg} / \mathrm{m}^{2}\right]^{*} \\
\mathrm{R}=0.07 \mathrm{p}=0.01 / \mathrm{X}^{2}=144.12 \mathrm{p}=0.000\end{array}$} & BMI* & \multicolumn{6}{|c|}{$R=0.12 p=0.000 / x^{2}=63.60 \quad p=0.000$} \\
\hline 66 & 17.84 & 0.58 & 17.49 & 18.09 & 18.28 & UW & 66 & 14.83 & 2.87 & \begin{tabular}{l|l}
12.73 \\
\end{tabular} & 14.63 & 17.21 \\
\hline 1246 & 21.45 & 1.57 & 20.22 & 21.32 & 22.62 & NW & 1246 & 16.50 & 2.95 & 14.48 & 16.37 & 18.45 \\
\hline 78 & 26.21 & 1.22 & 25.35 & 25.73 & 26.63 & OW & 78 & 20.26 & 3.15 & 18.30 & 20.10 & 22.15 \\
\hline 4 & 32.39 & 2.60 & 30.72 & 31.76 & 34.06 & OB & 4 & 20.71 & 9.35 & 15.18 & 24.82 & 26.23 \\
\hline 0 & & & & & & EOB & 0 & & & & & \\
\hline \multicolumn{6}{|c|}{$\begin{array}{l}\text { F on the back of an arm }[\mathrm{mm}]^{*} \\
R=0.07 \quad p=0.01 / X^{2}=13.09 \quad p=0.001\end{array}$} & $\mathrm{BMI}^{*}$ & \multicolumn{6}{|c|}{$\begin{array}{c}F \text { under scapula }[\mathrm{mm}]^{*} \\
R=0.09 p=0.01 / X^{2}=91.40 \quad p=0.000\end{array}$} \\
\hline 66 & 3.75 & 1.36 & 2.80 & 3.20 & 4.20 & UW & 66 & 8.61 & 2.17 & 7.40 & 8.30 & 10.00 \\
\hline 1246 & 3.96 & 1.62 & 3.00 & 3.40 & 4.40 & NW & 1246 & 11.37 & 3.82 & 8.80 & 10.40 & 13.00 \\
\hline 78 & 4.82 & 2.17 & 3.20 & 4.00 & 6.00 & OW & 78 & 18.18 & 6.66 & 14.00 & 17.50 & 21.40 \\
\hline 4 & 7.65 & 5.38 & 3.40 & 7.20 & 11.90 & OB & 4 & 21.80 & 14.24 & 10.90 & 24.30 & 32.70 \\
\hline 0 & & & & & & EOB & 0 & & & & & \\
\hline \multicolumn{6}{|c|}{$\begin{array}{c}\text { F on abdomen }[\mathrm{mm}]^{*} \\
R=0.12 \mathrm{p}=0.000 / \mathrm{X}^{2}=84.76 \mathrm{p}=0.000\end{array}$} & $\mathrm{BMI}^{*}$ & \multicolumn{6}{|c|}{$R=-0.12 p=0.000 / x^{2}=63.60 \quad p=0.000$} \\
\hline 66 & 7.46 & 2.34 & 5.80 & 7.00 & 8.20 & UW & 66 & 1.0606 & 0.0077 & 1.0542 & 1.0610 & 1.0662 \\
\hline 1246 & 9.87 & 4.04 & 7.20 & 9.00 & 11.80 & NW & 1246 & 1.0561 & 0.0078 & 1.0509 & 1.0564 & 1.0614 \\
\hline 78 & 17.28 & 6.67 & 12.80 & 15.70 & 22.00 & OW & 78 & 1.0462 & 0.0082 & 1.0413 & 1.0466 & 1.0513 \\
\hline 4 & 20.30 & 10.65 & 12.80 & 22.70 & 27.80 & $\mathrm{OB}$ & 4 & 1.0454 & 0.0249 & 1.0308 & 1.0344 & 1.0600 \\
\hline 0 & & & & & & EOB & 0 & & & & & \\
\hline
\end{tabular}

$U W$ - underweight; NW - normal weight; $O W$ - overweight; $O B$ - obesity; EOB - extreme obesity; $p$ - level of statistical significance; $R$ - rank order correlation Spearman coefficient; $\mathrm{X}^{2}-$ Kruskal-Wallis test; $F$ - the skin folds thickness on the right side of the body.

${ }^{*}$ Given the small number of observations in the category of obesity and lack of observation in the category extreme obesity, $R$ and $\mathrm{X}^{2}$ statistics were calculated only for the categories: underweight, normal weight and overweight. It should be noted that the significance remained at the same level as taking into account all categories of variable BMI facts. 
The value of the index calculated on the basis of BMI anthropometric measurements significantly correlated with body weight $(R=0.78 ; p=0.000)$, skin folds thickness under scapula $(R=0.59$; $p=0.000)$, on the back of an arm $(R=0.21 ; p=0.000)$, on abdomen $(R=0.0499 ; p=0.000)$, and with elements of the composition of body tissue: $D(R=-0.46 ; p=0.000), F \%(R=0.46 ; p=0.000), F k g$ $(R=0.69 ; p=0.000), T A \%(R=-0.46 ; p=0.000)$, TAkg $(R=0.69 ; p=0.000)$. As expected, there was no statistically significant correlation of BMI with the women's body height $(R=0.0087 ; p=0.7)$.

When examining the relationships between categories of real BMI and body weight, body height, real BMI, skin fold thickness, body density and the components of body tissue, there were significant correlations ( $\mathrm{p} \leq 0.05)$ between:

- categories of real BMI (underweight, normal weight, overweight) and the body weight, real BMI, $\mathrm{D}, \mathrm{F} \%$, the skin fold thickness (under scapula, on the back of an arm, on abdomen) (Tab. 2);

- categories of self-evaluated BMI (underweight, normal weight, overweight) and the body weight, real BMI, D, F\%, the skin fold thickness (under scapula, on abdomen) (Tab. 3);

- categories (underweight, normal weight) of the most satisfactory BMI (dreams) and body weight, real BMI (Tab.4).

There were no statistically significant correlations $(p>0.05)$ between:

- categories of real BMI (underweight, normal weight, overweight) and the body height (in accordance with the expectations associated with the definition of BMI) (Tab. 2);

- categories of self-evaluated BMI (underweight, normal weight, overweight) and the body height and the thickness of skinfolds on the back of an arm (Tab. 3);

Tab. 3. General characteristics of the quantitative variables - first-year female students of full-time studies at the Academy of Physical Education and Sport in Gdansk (2000-2007) - in categories of self-evaluation BMI

\begin{tabular}{|c|c|c|c|c|c|c|c|c|c|c|c|c|}
\hline $\mathrm{N}$ & $M$ & SD & Q25 & $\mathrm{Me}$ & Q75 & \multirow[b]{2}{*}{$\mathrm{BMI}^{*}$} & $\mathrm{~N}$ & $M$ & SD & Q25 & $\mathrm{Me}$ & Q75 \\
\hline \multicolumn{6}{|c|}{$\begin{array}{l}\text { Body weight [kg] * } \\
p=0.000 / X^{2}=127.99 \quad p=0.000\end{array}$} & & \multicolumn{6}{|c|}{$\begin{array}{l}\text { Body height [kg] * } \\
09 p=0.8 / x^{2}=3.298 \quad p=0.19\end{array}$} \\
\hline 33 & 51.39 & 5.52 & 47.70 & 49.70 & 55.60 & UW & 33 & 166.84 & 6.30 & 163.50 & 167.20 & 169.40 \\
\hline 578 & 58.68 & 6.01 & 54.50 & 58.20 & 62.00 & NW & 578 & 167.56 & 6.23 & 163.50 & 168.00 & 172.20 \\
\hline 265 & 65.31 & 7.46 & 60.30 & 65.00 & 70.00 & OW & 265 & 167.94 & 6.63 & 163.50 & 168.00 & 172.20 \\
\hline 6 & 63.65 & 7.95 & 60.00 & 63.25 & 71.20 & OB & 6 & 165.03 & 5.54 & 162.00 & 165.75 & 166.50 \\
\hline 3 & 66.57 & 7.84 & 57.80 & 69.00 & 72.90 & EOB & 3 & 166.17 & 8.31 & 157.00 & 168.30 & 173.20 \\
\hline \multicolumn{6}{|c|}{$\begin{array}{l}\text { Body Mass Index }\left[\mathrm{kg} / \mathrm{m}^{2}\right]^{*} \\
=0.36 p=0.000 / X^{2}=196.74 \quad p=0.000\end{array}$} & BMI* & \multicolumn{6}{|c|}{$\begin{array}{c}\mathbf{F} \% \text { * } \\
R=0.21 p=0.000 / x^{2}=67.18 \quad p=0.000\end{array}$} \\
\hline 33 & 18.44 & 1.45 & 17.46 & 18.42 & 18.85 & UW & 33 & 13.32 & 2.20 & 12.11 & 12.86 & 14.16 \\
\hline 578 & 20.87 & 1.48 & 19.83 & 20.71 & 21.80 & NW & 578 & 14.82 & 2.37 & 13.39 & 14.94 & 16.38 \\
\hline 265 & 23.12 & 1.88 & 21.83 & 22.99 & 24.26 & OW & 265 & 16.51 & 2.13 & 14.84 & 16.38 & 17.94 \\
\hline 6 & 23.29 & 1.74 & 21.77 & 23.59 & 24.25 & OB & 6 & 18.70 & 2.38 & 17.80 & 18.56 & 19.67 \\
\hline 3 & 24.23 & 3.79 & 20.41 & 24.30 & 27.99 & EOB & 3 & 17.59 & 2.01 & 16.04 & 16.88 & 19.86 \\
\hline \multicolumn{6}{|c|}{$\begin{array}{l}\text { F on the back of an arm }[\mathrm{mm}]^{*} \\
R=0.06 \quad p=0.09 / X^{2}=20.32 \quad p=0.000\end{array}$} & BMI* & \multicolumn{6}{|c|}{$\begin{array}{l}\text { F under scapula [mm }]^{*} \\
R=0.22 p=0.000 / X^{2}=76.55 \quad p=0.000\end{array}$} \\
\hline 33 & 2.85 & 0.41 & 2.60 & 2.80 & 3.00 & UW & 33 & 8.42 & 3.36 & 6.80 & 8.00 & 8.60 \\
\hline 578 & 3.08 & 0.56 & 2.80 & 3.00 & 3.40 & NW & 578 & 10.28 & 3.11 & 8.20 & 9.80 & 11.80 \\
\hline 265 & 3.21 & 0.52 & 2.80 & 3.20 & 3.40 & OW & 265 & 13.21 & 4.73 & 9.80 & 12.00 & 15.80 \\
\hline 6 & 3.60 & 0.42 & 3.20 & 3.70 & 4.00 & OB & 6 & 15.03 & 7.13 & 10.60 & 12.90 & 17.40 \\
\hline 3 & 3.40 & 0.80 & 3.70 & 3.40 & 4.20 & EOB & 3 & 16.00 & 8.37 & 10.20 & 12.20 & 25.60 \\
\hline \multicolumn{6}{|c|}{$\begin{array}{l}\text { F on abdomen [mm] } \\
p=0.000 / X^{2}=51.795 \quad p=0.000\end{array}$} & $\mathrm{BMI}^{*}$ & \multicolumn{6}{|c|}{$\begin{array}{c}D^{*} \\
R=-0.21 \quad p=0.000 / x^{2}=67.18 \quad p=0.000\end{array}$} \\
\hline 33 & 7.19 & 2.41 & 5.40 & 6.60 & 8.40 & UW & 33 & 1.0646 & 0.0059 & 1.0623 & 1.0658 & 1.0679 \\
\hline 578 & 8.61 & 3.04 & 6.40 & 8.20 & 10.00 & NW & 578 & 1.0606 & 0.0064 & 1.0564 & 1.0602 & 1.0644 \\
\hline 265 & 11.10 & 4.11 & 7.80 & 10.20 & 13.40 & OW & 265 & 1.0561 & 0.0056 & 1.0523 & 1.0564 & 1.0605 \\
\hline 6 & 15.33 & 6.27 & 11.00 & 14.00 & 19.60 & $\mathrm{OB}$ & 6 & 1.0503 & 0.0062 & 1.0477 & 1.0506 & 1.0526 \\
\hline 3 & 13.20 & 5.56 & 6.80 & 16.00 & 16.80 & EOB & 3 & 1.0532 & 0.0053 & 1.0472 & 1.0551 & 1.0573 \\
\hline
\end{tabular}

UW - underweight; NW - normal weight; OW - overweight; OB - obesity; EOB - extreme obesity; p - level of statistical significance; $R$ - rank order correlation Spearman coefficient; $x^{2}-$ Kruskal-Wallis test; $F-$ the skin folds thickness on the right side of the body

${ }^{* *}$ Given the small number of observations in the category of obesity and extreme obesity, $R$ and $x^{2}$ statistics were calculated only for the categories: underweight, normal weight and overweight. 
- categories (underweight, normal weight) of the most satisfactory BMI (dreams) and body height, $\mathrm{D}, \mathrm{F} \%$, the skin fold thickness (under scapula, on the back of an arm, on abdomen) (Tab. 4).

With successive categories of real and self-evaluated BMI (in the direction from underweight to overweight), there was a statistically significant increase in the value of body weight, real BMI, $\mathrm{F} \%$ and the skin fold thickness (under scapula, on the back of an arm, on abdomen). Also the height of the body reached increasingly higher values, although this diversity was not statistically significant (in accordance with expectations associated with the definition of BMI). By contrast, the density of the body in the direction from underweight to overweight significantly decreased. This is consistent with the widely-known relationship - the lower the density of the body, the greater fatness (Tab. 2, Tab. 3). Also, with successive BMI categories of the most satisfactory BMI (dreams) (in the direction from underweight to normal body weight), the value of the body weight and real BMI significantly increased. Also the body height, F\% and the skin fold thickness reached increasingly higher values, but they did not reach the observed variation at the level of statistical significance. Underweight women had an insignificantly higher body density than women with normal body weight (Tab. 4).

None of the surveyed female students dreamt of overweight, obesity or extreme obesity. They mostly wanted to have a normal body weight $(92.48 \%)$ or underweight $(7.52 \%)$. Only $3.73 \%$ students evaluated their BMI as underweight, while the anthropometric measurements indicated clearly that there was underweight in $4.73 \%$ students. A reverse dependency occurred in the overweight category. $29.94 \%$ students believed that they were overweight. By contrast, anthropometric measurements indicated that only $5.6 \%$ of students were overweight (Tab. 8 ).

Tab. 4. General characteristics of the quantitative variables - first-year female students of full-time studies at the Academy of Physical Education and Sport in Gdansk (2000-2007) - in categories of dream BMI

\begin{tabular}{|c|c|c|c|c|c|c|c|c|c|c|c|c|}
\hline $\mathbf{N}$ & M & SD & Q25 & Me & Q75 & \multirow[b]{2}{*}{$\mathrm{BMI}^{*}$} & $\mathbf{N}$ & $\mathbf{M}$ & SD & Q25 & Me & Q75 \\
\hline \multicolumn{6}{|c|}{$\begin{array}{c}\text { Body weight [kg] * }^{*} \\
R=-0.11 \quad p=0.008 / Z=2.63 \quad p=0.008\end{array}$} & & \multicolumn{6}{|c|}{$\begin{array}{l}{\text { Body height }[\mathrm{kg}]^{*}}^{*} \\
R=-0.03 \mathrm{p}=0.4 / \mathrm{Z}=0.77 \quad p=0.44\end{array}$} \\
\hline 46 & 58.14 & 5.83 & 54.50 & 57.10 & 61.80 & UW & 46 & 167.15 & 5.7 & 164.4 & 166.5 & 169.5 \\
\hline 566 & 61.06 & 7.63 & 55.80 & 60.30 & 65.60 & NW & 566 & 167.83 & 6.41 & 163.7 & 167.6 & 172.3 \\
\hline 0 & & & & & & OW & 0 & & & & & \\
\hline 0 & & & & & & OB & 0 & & & & & \\
\hline 0 & & & & & & EOB & 0 & & & & & \\
\hline \multicolumn{6}{|c|}{$\begin{array}{c}\text { Body Mass Index }\left[\mathrm{kg} / \mathrm{m}^{2}\right]^{*} \\
R=-0.10 \quad p=0.01 / Z=2.55 \quad p=0.01\end{array}$} & $\mathrm{BMI}^{*}$ & \multicolumn{6}{|c|}{$R=-0.07 p=0.10 / Z=1.63 p=0.10$} \\
\hline 46 & 20.797 & 1.63 & 20.06 & 20.75 & 22.03 & UW & 46 & 15.11 & 2.56 & 13.41 & 14.86 & 16.32 \\
\hline 566 & 21.64 & 2.07 & 20.18 & 21.49 & 22.88 & NW & 566 & 15.58 & 2.51 & 14.14 & 15.67 & 17.29 \\
\hline 0 & & & & & & OW & 0 & & & & & \\
\hline 0 & & & & & & OB & 0 & & & & & \\
\hline 0 & & & & & & EOB & 0 & & & & & \\
\hline \multicolumn{6}{|c|}{$\begin{array}{c}\text { F on the back of an arm }[\mathrm{mm}]^{*} \\
R=-0.06 \quad p=0.16 / Z=1.38 \quad p=0.17\end{array}$} & $\mathrm{BMI}^{*}$ & \multicolumn{6}{|c|}{$\begin{array}{c}\text { F under scapula [mm] } \\
R=-0.06 \quad p=0.15 / Z=1.46 \quad p=0.15\end{array}$} \\
\hline 46 & 3.04 & 0.45 & 2.80 & 3.10 & 3.20 & UW & 46 & 10.63 & 3.11 & 8.40 & 10.00 & 12.20 \\
\hline 566 & 3.18 & 0.60 & 2.80 & 3.20 & 3.40 & NW & 566 & 11.63 & 4.27 & 8.80 & 10.60 & 13.40 \\
\hline 0 & & & & & & OW & 0 & & & & & \\
\hline 0 & & & & & & OB & 0 & & & & & \\
\hline 0 & & & & & & EOB & 0 & & & & & \\
\hline \multicolumn{6}{|c|}{$\begin{array}{c}\text { F on abdomen [mm }]^{*} \\
R=-0.03 \quad p=0.47 / Z=0.72 \quad p=0.47\end{array}$} & $\mathrm{BMI}^{*}$ & \multicolumn{6}{|c|}{$\begin{array}{c}\mathrm{D}^{*} \\
\mathrm{R}=0.07 \mathrm{p}=0.10 / \mathrm{Z}=-1.63 \quad \mathrm{p}=0.10\end{array}$} \\
\hline 46 & 9.52 & 4.36 & 6.80 & 8.40 & 10.20 & UW & 46 & 1.0598 & 0.0068 & 1.0565 & 1.0604 & 1.0643 \\
\hline 566 & 9.60 & 3.69 & 7.00 & 9.00 & 11.60 & NW & 566 & 1.0585 & 0.0067 & 1.0539 & 1.0583 & 1.0624 \\
\hline 0 & & & & & & OW & 0 & & & & & \\
\hline 0 & & & & & & $\mathrm{OB}$ & 0 & & & & & \\
\hline 0 & & & & & & EOB & 0 & & & & & \\
\hline
\end{tabular}

UW - underweight; NW - normal weight; OW - overweight; OB - obesity; EOB - extreme obesity; $p$ - level of statistical significance; $R$ - rank order correlation Spearman coefficient; $\mathrm{X}^{2}-$ Kruskal-Wallis test; $F$ - the skin folds thickness on the right side of the body

${ }^{*}$ Given the small number of observations in the category of obesity and extreme obesity, $R$ and $x^{2}$ statistics were calculated only for the categories: underweight and normal weight. 


\section{BMI facts (anthropometric measurements) and self-evaluation BMI}

Of the 885 students who self-evaluated their BMI, 68.81\% students had accurate self-assessment (in accordance with the facts, that is, anthropometric measurements). By contrast, during self-evaluation $28.81 \%$ assessed their $\mathrm{BMI}$ as higher compared to the real $\mathrm{BMI}$, and $2.37 \%$ rated it as lower one. Women with underweight and normal body weight during self-evaluation raised their BMI value more often than underestimated it, unlike women with overweight. The latter ones tended to underestimate their BMI in relation to the facts. During self-evaluation BMI was assessed as higher by $48.57 \%$ of underweight women, by $29.17 \%$ of normal weight women, and by $5 \%$ of overweight women. By contrast, BMI was underestimated in self-evaluation by $1.85 \%$ of women with normal body weight and by $12.5 \%$ of overweight women. $82.5 \%$ of overweight students, $68.97 \%$ of students with normal body weight and $51.43 \%$ of underweight students assessed their BMI correctly (according to real BMI) (Tab.5).

\section{BMI facts (anthropometric measurements) and dreams of BMI (most satisfactory)}

As many as $89.13 \%$ students who want to be underweight had normal body weight (Tab. 6). Facts and dreams related to BMI were consistent in $85.13 \%$ students. Compliance of the dreams with facts was observed in $19.23 \%$ of underweight students, in $92.64 \%$ of students with normal body weight and in $0.0 \%$ of students who were overweight or obese (Tab. 6). By contrast, $11.44 \%$ of the women dreamt of lower BMI than that shown by anthropometric measurements, and $3.43 \%$ dreamt of higher BMI than the actual one. $80.77 \%$ of underweight students, $92.64 \%$ of students with normal body weight, and all overweight or obese students dreamt of normal body weight. By contrast, $19.23 \%$ of underweight students and $7.36 \%$ of students with normal body weight dreamt of underweight (Tab. 6).

\section{Self-evaluation BMI and dreams BMI (most satisfactory)}

Compliance of dreams with self-evaluation was observed in $59.97 \%$ students. Actual BMI felt wrong to as many as $40.03 \%$ female students: $36.76 \%$ dreamt of lower BMI, but only $3.27 \%$ of higher BMI (Tab. 7). However, the comparison of the facts with dreams (Tab. 6) shows that only $14.87 \%$ students should feel bad about their BMl (not $40.03 \%$ ): $11.44 \%$ (not $36.76 \%$ ) should dream about lower BMI, and 3.43\% (not 3.27\%) should dream of higher BMI. Students dream-

Tab. 5. Real BMI (N) and self-evaluation BMI (N) - first-year female students of full-time studies at the Academy of Physical Education and Sport in Gdansk (2000-2007)

\begin{tabular}{|c|c|c|c|c|c|c|c|}
\hline & & \multicolumn{5}{|c|}{ Self-evaluation BMI } & \\
\hline & & UW & NW & OW & $\mathrm{OB}$ & EOB & \\
\hline \multirow{5}{*}{ 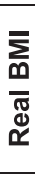 } & UW & 18 & 15 & 2 & 0 & 0 & 35 \\
\hline & NW & 15 & 558 & 229 & 5 & 2 & 809 \\
\hline & OW & 0 & 5 & 33 & 1 & 1 & 40 \\
\hline & OB & 0 & 0 & 1 & 0 & 0 & 1 \\
\hline & EOB & 0 & 0 & 0 & 0 & 0 & 0 \\
\hline & & 33 & 578 & 265 & 6 & 3 & 885 \\
\hline
\end{tabular}

UW - underweight; NW - normal weight; OW - overweight; $O B$ - obesity; EOB - extreme obesity; $N$ - number

Tab. 6. Real BMI (N) and dream BMI (N) - first-year female students of full-time studies at the Academy of Physical Education and Sport in Gdansk (2000-2007)

\begin{tabular}{|c|c|c|c|c|c|c|c|}
\hline & & \multicolumn{5}{|c|}{ Dream BMI } & \\
\hline & & UW & NW & OW & OB & $\mathrm{EOB}$ & \\
\hline \multirow{5}{*}{ 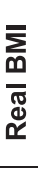 } & UW & 5 & 21 & 0 & 0 & 0 & 26 \\
\hline & NW & 41 & 516 & 0 & 0 & 0 & 557 \\
\hline & OW & 0 & 28 & 0 & 0 & 0 & 28 \\
\hline & $\mathrm{OB}$ & 0 & 1 & 0 & 0 & 0 & 1 \\
\hline & EOB & 0 & 0 & 0 & 0 & 0 & 0 \\
\hline & & 46 & 566 & 0 & 0 & 0 & 612 \\
\hline
\end{tabular}

$U W$ - underweight; NW - normal weight; OW - overweight; OB - obesity; EOB - extreme obesity; N-number 
Tab. 7. Self-evaluation BMI $(N)$ and dreams BMI $(N)$ - first-year female students of full-time studies at the Academy of Physical Education and Sport in Gdansk (2000-2007)

\begin{tabular}{|c|c|c|c|c|c|c|c|}
\hline & & & & & & \\
\hline & & \multicolumn{5}{|c|}{ Dreams BMI } & \\
\hline & & UW & NW & OW & OB & $\mathrm{EOB}$ & \\
\hline \multirow{5}{*}{ 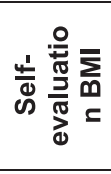 } & UW & 1 & 20 & 0 & 0 & 0 & 21 \\
\hline & NW & 25 & 366 & 0 & 0 & 0 & 391 \\
\hline & OW & 19 & 173 & 0 & 0 & 0 & 192 \\
\hline & $\mathrm{OB}$ & 0 & 5 & 0 & 0 & 0 & 5 \\
\hline & EOB & 1 & 2 & 0 & 0 & 0 & 3 \\
\hline & & 46 & 566 & 0 & 0 & 0 & 612 \\
\hline
\end{tabular}

$U W$ - underweight; NW - normal weight; OW-overweight; $O B$ - obesity; EOB - extreme obesity; $N$ - number

Tab. 8. Underweight, normal weight, overweight, obesity, extreme obesity in the context of real BMI, self-evaluation BMI, dream BMI - first-year female students of full-time studies at the Academy of Physical Education and Sport in Gdansk (2000-2007)

\begin{tabular}{|c|c|c|c|c|c|c|}
\cline { 2 - 7 } \multicolumn{1}{c|}{} & \multicolumn{2}{c|}{$\begin{array}{c}\text { Real } \\
\text { BMI }\end{array}$} & \multicolumn{2}{c|}{$\begin{array}{c}\text { Self-evaluation } \\
\text { BMI }\end{array}$} & \multicolumn{2}{c|}{$\begin{array}{c}\text { Dream } \\
\text { BMI }\end{array}$} \\
\hline BMI & $\mathrm{N}$ & $\%$ & $\mathrm{~N}$ & $\%$ & $\mathrm{~N}$ & $\%$ \\
\hline Underweight & 66 & 4.73 & 33 & 3.73 & 46 & 7.52 \\
\hline Normal weight & 1246 & 90.67 & 578 & 65.31 & 566 & 92.48 \\
\hline Overweight & 78 & 5.595 & 265 & 29.94 & 0 & 0.00 \\
\hline Obesity & 4 & 0.29 & 6 & 0.68 & 0 & 0.00 \\
\hline Extreme obesity & 0 & 0.00 & 3 & 0.34 & 0 & 0.00 \\
\hline
\end{tabular}

ing of underweight most frequently evaluated their BMI as accurate $(54.35 \%)$, then as overweight $(41.30 \%)$, and only one person felt her BMI should be classified as underweight (i.e. in accordance with her dreams), and one person as a very high obesity (Tab. 7). Students dreaming of normal BMI, most frequently assessed their BMI as normal $(64.66 \%)$, then as overweight $(30.57 \%)$, underweight $(3.53 \%)$, obese $(0.88 \%)$ or extremely obese $(0.35 \%)$ (Tab. 7$)$.

\section{Discussion}

Body Mass Index (BMI) is a widely-used measure of the nutritional status [1]. BMI correlates with the total content of fat in the body, which was observed in the tested group of young women (Tab. 2) [10]. Moreover, as is commonly known, BMI is not significantly correlated with body height, which is also beneficial in assessing the nutritional status (Tab. 2). It is well known that students' diet in many cases differs from recommendations of international organizations dealing with this issue. The most common irregularities regard an inappropriate number of meals and irregularities in their consumption [16].

The consequence of such behaviour is abnormal BMI index values, which, in turn, is often associated with significant problems including psychological and social low self-esteem and social isolation. As a result, very often one's own body image or its vision generated under the influence of internal stimuli are not consistent with the actual state.

In the studied group of students the discrepancy between real BMI and self-evaluated BMI amounted to $31.19 \%$ (Tab. 5). Only $68.81 \%$ of the students evaluated their BMI according to anthropometric measurements. As many as $28.81 \%$ assessed their BMI as higher, while only $2.37 \%$ rated it lower than anthropometric measurements indicated (Tab. 5).

Overrating BMI by women more often than underrating it during BMI self-evaluation is a wellknown phenomenon $[17,18,19]$. Among others the following works $[3,5,6,17,18,19,20,21,22,23$, $24,25,26,27,28,29,30]$ indicated the discrepancy between the actual and self-evaluated BMI.

Own body image is an important component of mental welfare, strongly dependent on gender, age, geographical region, cultural behaviours and habits. In a study of young women in Taiwan, Wong [17] noted overweight or obesity in $16.2 \%$ women, while in self-evaluation these women indicated such values of BMl three times more frequently $(51.4 \%)$. 
In the group of Gdansk students, these differences are even more pronounced, which is probably largely related to the type of university where they study. They want to be lean, muscular, with a minimum percentage of body fat. Overweight or obesity occurred in $5.9 \%$ of students. By contrast, during self-evaluation $30.62 \%$ of the women declared overweight or obesity (Tab. 8). During the self-evaluation by Miller [31] overweight women were evaluated at $46 \%$, which is higher than the result obtained in the group of students at the Academy of Physical Education and Sport in Gdansk (28.81\%) (Tab. 5). In particular, women overestimate their BMI - even when the BMI is normal (Tab. 5) $[3,5,18,19,23,31]$. In self-evaluation among the tested group of students $29.17 \%$ of women with normal body weight claimed to have higher BMI, and only $1.85 \%$ to have a lower one (Tab. 5). This is a very worrying phenomenon, since as mentioned by Mandal [23], during self-evaluation the weight of women with normal body weight is accompanied by depressive disorders, low self-esteem, and subjective assessment of their own appetite as too high. An extreme example of this phenomenon is anorexia nervosa, when a patient sees a lean body as too fat [5]. Underestimating their body weight during self-evaluation, as opposed to overstatement, is a much less common phenomenon. Among Gdansk students understatement was present in only $2.37 \%$ of students (1.85\% of normal body weight and $12.5 \%$ overweight (Tab. 5). Not just their own body image, but also being pleased with its composition (BMI) is quite varied and dependent, among other things, on gender, age, geographical region, cultural behaviours and habits. In this group of young women, $59.97 \%$ are satisfied with their BMI (self-evaluation and dreams overlap) (Tab. 7).

A similar result (63\%) was obtained by Hoffman [32] among young women (aged 14-19). In 1997 Melone noted a much lower proportion (31\%) of women satisfied with their weight among women of the European Union [33]. In turn, in the studies by Nunes et al. [34], 42\% of women aged 14-55 years were satisfied with their body weight. Own research and scientific reports clearly indicate that young people, especially growing up women, have difficulty in self-evaluation of body weight adequate to reality. They usually claim that they have excessive body weight. Even dreams are different from facts (Tab. 7). Overweight in self-evaluation is related to the fact, among other things, that they mainly look for normal weight or underweight (Tab. 6, Tab. 7, Tab. 8).

The reasons for inadequate self-evaluation and BMI differences between the facts, dreams and self-evaluation are complicated. On the one hand, they are associated with changes in going through adolescence and entering adulthood (these changes mainly regard the composition and proportions of the body), forming their own identity and a new image of the body. On the other hand, the idea of "slim is better" is omnipresent. Patterns demonstrated in mass media and television advertisements often state that one must be slim. Therefore, young women carry out the assessment of their own bodies mainly through a comparison to the universally accepted ideal of femininity - lean body [24,26].

\section{Conclusions}

BMI assessment should not be based solely on the information obtained in young women's self-evaluation. Education is necessary for continuous monitoring and improving dimensions of one's body.

Women examined at the turn of adolescence and adult age women do not have proper skills to assess their BMI, which, in turn, can lead to eating disorders. There is, therefore, a high probability of undue and improper weight loss often due to inadequate nutrition, which can result in serious health consequences. Dealing with this behaviour should be an important part of prohealth education, particularly among young people.

There is, therefore, a need to teach children and young people objective methods of assessing body weight, especially by nurses during the screening procedures and in other situations where measurements of body weight and height are made. 


\section{References}

1. Malinowski A, Strzałko J, eds. Antropologia. Autekologia człowieka [In Polish] [Anthropology. Human autecology]. Warszawa-Poznań: PWN; 1989, 378-387.

2. Jaśko J, Kamecka-Krupa J. Czynniki ryzyka anoreksji [in Polish] [Risk factors in anorexia] Prob Hig Epidemiol 2007;88(3):254-258.

3. Cachelin FM, Rebeck RM, Chung GH, Pelayo E. Does ethnicity influence body-size preference? A comparison of body image and body size. Obes Res 2002;10(3):158-166.

4. Melosik Z. Tyrania szczupłego ciała i jej konsekwencje [in Polish] [The slim body tyranny and its consequences]. In: Melosik Z, ed. Ciało i zdrowie w społeczeństwie konsumpcji [Body and health in a consummerist society. ToruńPoznań: Edytor; 1999, 139-158.

5. Bąk-Sosnowska M, Mandal E, Zachorska-Markiewicz B. Związek nieadekwatnego wyobrażenia własnego ciała $\mathrm{z}$ nadwagą u kobiet [in Polish] [Relation between non adequate imaginary picture of personal body and the overweight at women]. Ann Acad Med Siles 2006;60(5):385-390.

6. Boschi V, Siervo M, D'orsi P, et al. Body composition, eating behavior food-body concerns and eating disorders in adolescent girls. Ann Nutr Metab 2003;47(6):284-293.

7. Jestes D. Body image: how you see it, how you don't.http://www.clearinghouse.mwsc.edu/manuscripts/93.asp [accessed 12.04.1994].

8. Yanowski J, Yanowski SZ. Recent advances in basic obesity research. JAMA 1999;282:1504-1506.

9. Pi-Suyner FX. The obesity epidemic pathophysiology and consequences of obesity. Obesity Res 2002;10 (suppl.2): 975-1045.

10. Kinalska I, Popławska-Kita A, Telejko B, Kinalski M, Zonenberg A, Otyłość a zaburzenia przemiany węglowodorowej [in Polish] [Obesity and carbohydrate metabolism]. Endokrynologia, Otyłość, Zaburzenia Przemiany Materii 2006;2(3):94-101.

11. Wójtowicz E. Występowanie chorób sercowo-naczyniowych wśród rodziców studentów i studentek I roku studiów dziennych Akademii Wychowania Fizycznego i Sportu w Gdańsku [in Polish] [Occurrence of cardiovascular diseases in the parents of the first-year daily students at the Academy of Physical Education and Sport in Gdansk]. Annales Universitatis Mariae Curie-Skłodowska 2004;LIX, suppl.XIV,565, Sectio D:435-440.

12. Wójtowicz E. Gender, age, body weight, BMI, physical activity of adults and probability of the appearance of chronic diseases. In: Mosiewicz J, ed. Risk factors and prevention in a fight for health and wellness. Lublin: Wydawnictwo NeuroCentrum, XXXVII;2008:337-344.

13. Stoke R, Recascino $\mathrm{CH}$. Women's perceived body image: relations with personal happiness. J Women Aging 2003;15:17-30.

14. Piechaczek H. Oznaczanie całkowitego tłuszczu ciała metodami densytometryczną i antropometryczną [in Polish] [Determining total body fat with denisitometric and anthropometric methods]. MPA 1975;89:3-48.

15. WHO. Global database on Body Mass Index: BMI classification, http://apps.who.int/bmi/index.jsp?introPage= intro_3.html [accessed 18.11.2010]

16. Mięsowicz I, Palus D. Zachowania prozdrowotne studentów Akademii Pedagogiki Specjalnej [in Polish] [Pro-health behaviours in students at the Academy of Special Pedagogy]. In: Malinowski A, Tatarczuk J, Sienkiewicz R, eds. Ontogeneza i promocja zdrowia w aspekcie medycyny, antropologii $i$ wychowania fizycznego [Ontogenesis and health promotion in view of medicine, anthropology and physical education]. Zielona Góra: Oficyna Wydawnicza Uniwersytetu Zielonogórskiego; 2002, 182-189.

17. Wong Y, Huang YC. Obesity concerns, Weight satisfaction and characteristics of female dieters: a study on female Taiwanese college students. J Am Coll Nutr 1999;18(2):194-200.

18. Wójtowicz E. Stopień urbanizacji środowiska a samoocena BMI młodzieży akademickiej [in Polish] [The degree of urbanisation of the environment and BMI self-evaluation in academic youth]. In: Zagórski J, Popławska H, Skład $\mathrm{M}$, eds. Uwarunkowania rozwoju dzieci i młodzieży wiejskiej [Determinants of the development of rural children and youth]. Lublin: Instytut Medycyny Wsi; 2004, 213-222.

19. Wójtowicz E. Masa ciała w ocenie studentów i studentek Akademii Wychowania Fizycznego i Sportu w eyes of first year male and female sex students at the Academy of Physical Education and Sport in Gdansk]. Annales Universitatis Mariae Curie-Skłodowska LVIII, suppl.XIII, 565, Section D, 2003:513-518.

20. Stoke R, Recascino $\mathrm{CH}$. Women's perceived body image: relations with personal happiness. J Women Aging 2003;15:17-30.

21. Cash T, Hicks K. Being fat versus thinking fat: relationship with body image, behaviors and well-being. Cognit Ther Res 1990;14:327-341.

22. Rabe-Jabłońska J, Dunajska A. Poglądy na temat zniekształconego obrazu ciała dla powstania i zaburzeń odżywiania [in Polish] [Views on a distorted body image for appearance of eating disorders]. Psychiatria Polska 1997; 31:723-738.

23. Mandal E. Podmiotowe i interpersonalne konsekwencje stereotypów związanych z płcią. [in Polish] [Subjective and interpersonal consequences of gender stereotypes]. Katowice: Wydawnictwo Uniwersytetu Śląskiego, 2000.

24. Abraham SI. Dieting, body weight, body image and self esteem in young women: doctor's dilemmas. Med $J$ Aust 2003:178(12):607-611. 
25. Kilpatrick M, Ohannessian C, Bartholomew JB. Adolescent weight management and perceptions: on analysis of the National Longitudinal Study of Adolescent Health. J School Health 1999;69:148-152.

26. Kołoło H, Woynarowska B. Self-perception of body mass and dieting in adolescents. Przegląd Pediatryczny 2004;34:196-201.

27. Mable HM, Balance WD, Galgan RJ. Body-image distortion and dissatisfaction in university students. Percept Mat Skills 1986;63(2Pt2):907-911.

28. Connor-Greene PA. Gender differences in body weight perception and weight-loss strategies of college students. Women Health 1988;14(2):27-42.

29. Gray SH. Social aspects of body image: perception of normalcy of weight and affect of college undergraduates. Percept Mot Skills 1977;45 (3Pt2):1035-1040.

30. Rasheed P. Perception of body weight and self-reported eating and exercise behavior among obese and nonobese women in Saudi Arabia. Public Health 1998;112(6):409-414.

31. Miller TM, Coffman JG, Linke RA. Survey on body image, weight, and diet of college students. Am Diet Assoc 1980; 77(5):561-566.

32. Hoffman-Muller B, Amstad H. Body image, weight and eating behavior in adolescents. Schweiz Rundsch Med Prax 1994;83(48):1336-1342 [in German].

33. McElhone S, Kearney JM, Giachetti I, Zunft HJ, Martinez JA. Body image perception in relation to recent weight changes and strategies for weight loss in a nationally representative sample in the European Union. Public Health Nutr 1999; 2(1A):143.

34. Nunez C, Carbajal A, Moreiras O. Body mass index and the desire of weight loss in a group of young women. Nutr Hosp 1998;13(4):172-176 [in Spanish]. 